\title{
VERTICAL LAND UTILIZATION BY MEANS OF STOREY HOUSING DEVELOPMENT IN URBAN AREA
}

\author{
Arie Sukanti $\mathbf{S}^{1}$
}

\begin{abstract}
Many international covenants and constitutions have recognized housing and shelter needs as one of many human right aspects. This paper intends to clarify the particular issues relating to paragraph 19 of the United Nations Millennium Declaration, on resolving city slum problems. The Declaration has also embedded initiative to achieve a significant improvement in the lives of at least 100 million slum dwellers as proposed in the "Cities without Slums" by 2020. In the local perspectives, based on existing regulations analysis, the Special Region (DKI) of Jakarta has many problems on forthcoming implementation. Vertical land utilization model by way of storey houses development becomes an alternative to settle the demographic and housing problems. More legal research needs to be conducted to find the best effective national policy in the future. Urban land use, proposed as starting points, will be able to explore how to provide and undertake vertical land utilization and city planning to resolve city slums problems by providing both housing needs and city attractiveness as an integrated planning.
\end{abstract}

\section{Introduction}

\section{Problem Background}

Rapid development in urban area in Indonesia has taken place in the last decade. One of the very important factors, which has become the attention of all parties, is the population aspect and various inherent problems, which entails the dynamic of urban area development. Budhy Tjahjati S. Soegijoko² (1999) once presented that the total number of urban area population has increased with the pace of 5.5 per cent per year from 1980 to 1990; much higher than the average growth of national population, which is only 1.97 per cent per year. Such condition has caused the increased proportion of population living in urban area; from 32.8 million people or 22 per cent of the total population in 1980 to approximately 65 million people or 35 per cent in 1993 .

The total number of Indonesian population in 2018 is estimated to reach approximately 260 million persons, of which the urban area population will be approximately 155 million or nearly 60 per cent of the total population. This estimation is based on the assumption that we manage to decrease the pace of population growth from 1.7 per cent in 1992 to less than 0.9 per cent in 2018

${ }^{1}$ Professor of Law at Faculty of Law University of Indonesia

2 Budhy Tjahjati S. Soegijoko, "National Policy for Urban Area in entering into the Third Millennium". Paper was presented at National Seminar on City Lay Out Entering Into the Third Millennium, September $14,1999$. 
(at the end of the second long term development). Meanwhile, in DKI Jakarta, the population keep on increasing throughout the year 1961-2000. In 1961, the total number of population of DKI Jakarta only reached 2.91 million people. It increased to 4.55 million people in 1971, 6.48 million people in 1980, 8.23 million in 1990, and at the end of the year 2000, it was estimated to reach 9.72 million people.

The mobility of population towards urban area (urbanization) in Indonesia rapidly increased; demonstrated by the extremely high number of city population growth, especially in the period of 1980-1990 (7.85 percent per year). The growth level of city population has greatly decreased to 2.01 percent during the period of 1990-2000; however, based on the percentage of population living in the city, it appears to increase rapidly. The Indonesian Population Census records the percentage of city population in Indonesia in 1980 as only 22.38 percent; this has increased to 35.91 percent in 1990 . Ten years later (in 2000 ), the city population in Indonesia has reached 42.43 per cent. $^{3}$

In addition, cities in Indonesia face various problems directly influencing the city materialization effort as expected in the forthcoming third millennium. Internally, the city faces problems of urbanization, employment opportunities, conflict of space utilization, slum area, etc. Meanwhile external problems include the existence of gaps between village and city, inter-cities, and inter-groups in the city. Problems in urban area have become more intense, especially with the economic crisis, which has persisted since the mid-1997. The problems are, among others: (a) the drastic decrease of working opportunity, resulting in the increased number of unemployment; (b) the decrease of government fund availability to develop/maintain urban area infrastructure and facility; (c) the decrease of community's purchasing power; (d) the increase of number of poor community in urban area; and (e) the decline of environmental quality in urban area. $^{4}$

The development of cities in Indonesia will also face various new challenges as a logical consequence to the enactment of development decentralization policy to regency/city government, post the effective implementation of Law number 22 of the Year 1999 regarding Regional Governance ${ }^{5}$. Regency/city government has full authority in implementing and managing development in its region. The management of development in cities becomes the responsibility of regional government, from the planning to the controlling of its development. Additionally, the source of its funding becomes the responsibility of regional government ${ }^{6}$.

On the other hand, the emerging trend in urban area in Indonesia stimulates the increase of city construction activity in the form of large-scale new construction such as the construction of multifunctional buildings as

3 Data is processed from Statistic Centre Bureau in the year 1982, 1992 and 2001.

4 Budhy Tjahjati S. Soegijoko, op.cit. page 4. In addition, specifically become the highlight of problems in this paper is the elaboration of various aspects described by Budhy Tjahjati S. Soegijoko in two fundamental problems observed from the population aspect and land affairs and can also be provided initial hypothesis in relation to interdependency factor between population factor and land supporting power according to the principles of sanitation, environmental supporting power, social-economy capability, human behavior and urban area lay out, which must be able to be formulated and accommodated in urban policy.

${ }^{5}$ been revised by Law Number 32 of the Year 2004

${ }^{6}$ The Law can be accessed at http://prokum.esdm.go.id/uu/1999/uu-22-1999.pdf and http:// www.kpu.go.id/dmdocuments/UU_32_2004_Pemerintahan\%20Daerah.pdf 
well as super-block, which combines office area, trade center and apartment supplemented by other various supporting facilities. Such trend is a way to adjust such massive development with the potentials of its environmental resources and supporting power.

Another relevant challenge is the agenda related to the population stipulated by UNO in the United Nations Millennium Declaration, paragraph 19, which stipulates, among others:

"To halve, by the year 2015, the proportion of the world's people whose income is less than one dollar a day and the proportion of people who suffer from hunger and, by the same date, to halve the proportion of people who are unable to reach or to afford safe drinking water.

To ensure that, by the same date, children everywhere, boys and girls alike, will be able to complete a full course of primary schooling and that girls and boys will have equal access to all levels of education.

By the same date, to have reduced maternal mortality by three quarters, and under-five child mortality by two thirds, of their current rates.

To have, by then, halted, and begun to reverse, the spread of HIV/AIDS, the scourge of malaria and other major diseases that afflict humanity.

To provide special assistance to children orphaned by HIV/AIDS.

By 2020, to have achieved a significant improvement in the lives of at least 100 million slum dwellers as proposed in the "Cities without Slums" initiative."

It is apparent that the last part of paragraph 19 emphasizes on the effort to improve slum environment, which is expected to reach the target of "cities without slums" program by 2020. In addition to the Declaration, such emphasis is also found in the Habitat Agenda, paragraph 25: Adequate shelter for all which is delivered in the United Nations Conference on Human Settlements (Habitat II). ${ }^{7}$

The focus on humanity problems addressed in paragraph 25 is based on experience in various urban areas in the world affected by various injustice practices in the construction, social injustice, the emerging of negative impact in various forms of crimes, social turmoil, poverty, unemployment and the numerous homeless people associated with the growing of slum area. Paragraph 25 generates commitment for participating countries to settle humanity issues based on the principles of equality, solidarity, partnership, human dignity, respect and cooperation.

Aware of such commitment, paragraph 25 also provides reference for the settlement of population and housing issues by affirming, "We adopt the goals and principles of adequate shelter for all and sustainable human settlements development in an urbanizing world". The principle of adequate shelter for all

\footnotetext{
${ }^{7}$ Only 10 countries from 23 countries being surveyed (approximately 40\%) who have action plan which is based on legal policy and improvement, which stipulate clear target, form supporting institutions, and stipulate programs in large scale. They are: Brazil, Burkina Faso, Cambodia, Colombia, Costa Rica, Indonesia, Morocco, Namibia, the Philippines, and South Africa. On the other edge of the spectrum, several countries are remaining hesitant as can be observed from the responses to the questioner. Quoted from sources: http://www.menlh.go.id/serasi/serasi2.pdf?PHPSESSID=5db84684beae38b17c9057523c5300 $\mathrm{db}$, accessed on April 12, 2006
} 
is understood as an effort to improve stability and more just world, free from injustice and conflict, and will create justice, lasting and comprehensive peace. ${ }^{8}$

To give reference to the implementation of housing construction, guidance is provided in paragraph 69(a) with the title Coordinating and integrating shelter and human settlements with, inter alia, land policies as follows:

\section{"Habitat Agenda paragraph 69(a):}

69. To adopt and implement a cross-sectoral approach to policy development, Governments at the appropriate levels, including local authorities, should:

(a) Coordinate and integrate shelter and human settlements policies with other related policies, such as population and human resources development policies, environment, cultural, land and infrastructure policies, urban and rural planning, as well as private and/or public employment initiatives;"

In the construction of urban area, especially housing, roads and transportation infrastructures, and other public utilities, as have been stipulated in the City Spatial Planning, obtaining land is increasingly difficult. This is due to the unreasonable increase in the price of urban area land, whereas the government budget is not sufficient to meet the demand for the construction of such public facilities.

On the other hand, in general, land in urban area and suburbs have been acquired by the community. Therefore, land procurement for construction activity is becoming more difficult due to the limited fund for land compensation since the price continues to increase. Thus far, land procurement for the construction of urban area housing/settlement conducted conventionally by means of land release from its owner has caused more problems; for example, the presence of land speculators, land relinquishment, which evict the local community, exclusive settlements, imbalance procurement of urban area facility and infrastructure, etc.

The amount of compensation for land acquisition is often considered insufficient by the landowners. This leads to further problems wherein the landowners who disagree to the amount of compensation put their land under following:

8 The complete content of paragraph 25 of Habitat Agenda: Adequate shelter for all is as 25. We, the States participating in the United Nations Conference on Human Settlements (Habitat II), are committed to a political, economic, environmental, ethical and spiritual vision of human settlements based on the principles of equality, solidarity, partnership, human dignity, respect and cooperation. We adopt the goals and principles of adequate shelter for all and sustainable human settlements development in an urbanizing world. We believe that attaining these goals will promote a more stable and equitable world that is free from injustice and conflict and will contribute to a just, comprehensive and lasting peace. Civil, ethnic and religious strife, violations of human rights, alien and colonial domination, foreign occupation, economic imbalances, poverty, organized crime, terrorism in all its forms, and corruption are destructive to human settlements and should therefore be denounced and discouraged by all States, which should cooperate to achieve the elimination of such practices and all unilateral measures impeding social and economic development. At the national level, we will reinforce peace by promoting tolerance, non-violence and respect for diversity and by settling disputes by peaceful means. At the local level, the prevention of crime and the promotion of sustainable communities are essential to the attainment of safe and secure societies. Crime prevention through social development is one crucial key to these goals. At the international level, we will promote international peace and security and make and support all efforts to settle international disputes by peaceful means, in accordance with the Charter of the United Nations. 
enclave, which subsequently hinders the development. On the other side, eviction or resettlement of population often has social-economic impact such as financially impairing vulnerable community groups.

The continuous expansion of urban area construction also results in other negative impacts, such as decreasing of green open space. The need for open space remains important for the population in urban area, which is filled with human activity and operation of vehicles, office, factory, other public utility a potential for sound and air pollution. Furthermore, due to the need for land for urban area construction, land acquisition expands into the suburban area, changing the utilization over fertile farmland for non-cultivation purposes.

\section{Main problem}

From the description in the previous problem background, this paper will describe the problems to be addressed herein as follows:

1. What is the possibility for applying vertical housing construction (by socalled "Satuan Rumah Susun" System/SRS which is kind of strata title in Singapore, New South Wales or by leasing system) in the framework of solving population and slum area problems in urban area?

2. What factors would support or impede the application of vertical housing construction in the framework of solving population and slum area issues in urban area?

\section{Objectives of writing}

In line with the focus of problems stipulated above, the objectives of this paper are as follows:

3. Elucidate the concept of storey housing construction through SRS system in a normative nature, supplemented by theoretical basis and comparison to similar experience in other countries related to its application as the solution for population and slum area issues in urban area.

4. Elucidate the supporting and impeding factors for the application of vertical housing construction in the framework of solving population and slum area issues in urban area. It includes elaboration of various research data and result on the population issues in urban area and recommendation for solving the problems.

\section{Vertical Land Utilization by Means of Storey Housing Development in Urban Area}

The condition of urban area as described above is not a problem in developing countries, it is also in the United States of America. The National Center for Analysis Policy in the United States of America once published a brief analysis from the writing of Samuel R. Stanley titled, "The Sprawling of America: In Defense of the Dynamic City". ${ }^{9}$ In his writing, Samuel R. Stanley (1999) states that slum area in urban area has reflected national debate towards the land use policy. Serious problems faced by 19 states can be observed from the formulation

${ }^{9}$ Samuel R. Stanley with the title "The Sprawling of America: In Defense of the Dynamic City," Policy Study 251 January 1999, reason Public Policy Institute published in the Brief Analysis of National Center for Analysis Policy no. 287, March 24, 1999. 
of statutory regulation or the formation of task force to protect farmland and open space from the pressure of changes for other utilization and usage in the framework of city construction. Many major and middle-class cities have applied limitation for the development of city only in certain area and prevent the spreading of urbanization. Moreover, the Clinton administration proposed to bring forward the slum issue occurring in this urban area as a federal issue.

The above illustration is intended to inspire parts of the settlement effort for the population issue in urban areas in Indonesia, since major cities in Indonesia, such as Jakarta, Surabaya, Medan, have cross-sectoral and crossprovincial problems and subsequent complexities.

The opinion of Samuel R. Stanley, which states that slum area in urban area has reflected national debate in land use policy, will be used as an initial reference for the settlement of population issue in this paper. The following description will be preceded by an explanation on the aspects of land use planning and control in urban area. The subsequent description will explain the concept of housing construction with storey housing system according to the prevailing laws. Those two variables will be explained as one integral and inseparable concept as there is a correlation between the construction of storey housing and the land use in urban area related to its planning and control aspects.

\section{Planning and Control over Land Use in Urban Area}

Land use planning, according to Law number 24 of 1992 regarding Spatial Planning, is conducted through formation process and procedure (land use plan regulation). Spatial planning is conducted by considering:

a. Harmony, conformity, and balance between cultivation function and sheltering function, the dimension of time, technology, social culture, and defense and security function;

b. Aspect of integrated management of various environmental resources, function and aesthetic, and the quality of space.

Space utilization is conducted through the implementation of space utilization program and its financing, based on the lay out plan. Space utilization aforesaid is conducted gradually in accordance with the period stipulated in the lay out plan.

In space utilization, being developed:

a. management pattern of land use, water use, air use, and the use of other natural resources in accordance with the principle of lay out arrangement

b. incentive and disincentive instruments with due observance of the right of residents as citizen. ${ }^{10}$

\section{Control over space utilization is organized through supervising and}

\footnotetext{
${ }^{10}$ Furthermore, incentive and disincentive in the framework of land use fostering and controlling in Article 28 of the Government Regulation No. 16 of the year 2004 regarding Land Use Arrangement, it is elucidated that incentive instrument is an arrangement having the objective of giving stimulation towards activity in accordance with the objective of land use arrangement; whereas disincentive is arrangement having the objective of limiting or decreasing activities disaccord with the objective of land use arrangement, for example, among others, in the form of re-evaluation towards the right over land, and the imposition of high tax. Re-evaluation towards the right over land is based on the provisions as meant in the government regulation regarding the administration and efficiency of abandoned land.
} 
administrating activities regarding space utilization. Supervision over space utilization is organized in the form of reporting, monitoring, and evaluation.

\section{Storey housing with SRS System}

The development of storey housing is one of the alternative solutions for the issue of housing and shelter necessity, especially in urban areas where population keeps on increasing, because it can lessen land utilization, dispose much more spacious city open spaces, and be used as a method for city revitalization in the slum. Such city revitalization has been proclaimed in the Presidential Instruction Number 5 of 1990, the Revitalization of Slum Settlement on State Land.

As a follow up to the Presidential Instruction, Circular Letter Number 04/ SE/M/1/1993 dated January 7, 1993 was issued to the governors of the First Level Regions (Daerah Tingkat I?) and the Regents/Mayors of the Second Level Regions (Daerah Tingkat II). It is aimed at implementing general guidelines for the integral handling of slum housing and settlement, which among others, is conducted through revitalization and the construction of storey housing.

However, there is a brief elucidation with regard to SRS system (condominium) according to the provisions of Law Number 16 of 1985 and the Government Regulation Number 4 of 1988, which become the legal basis and objectives for the construction of storey housing ("Rumah Susun"). In addition, there are also other related statutory regulations. ${ }^{11}$

\section{Basic concept of SRS System.}

Based on Indonesia Law Number 16 of 1985, Rumah Susun with SRS system is a multi-storied building constructed in an environment, divided into parts that are functionally structured horizontally and vertically and constituting units which respectively may be owned and used separately, especially for residential, supplemented by common-parts, common-goods, and commonland.

\section{Land For the development of Rumah Susun with SRS System}

Rumah Susun may only be constructed upon land with Right of Ownership (Hak Milik/HM), Right to Build (Hak Guna Bangunan/HGB), Right of Use over

${ }^{11}$ The intended statutory regulations are:

a. Presidential Instruction number 5 of the year 1990 regarding Revitalization of Slum Settlement on State Land

b. Regulation of the Minister of Public Works No. 60/PRT/1992 and its additional/amending regulations.

c. Registration of the Deed of SRS Separation and the issuance of the Certificate of Right of Ownership over SRS unit must comply with the provisions of the Regulation of Chairman of the National Land Agency No. 2 of the Year 1989 regarding the Form and Procedure for the Filling-in and Registration of the Deed of SRS Separation and the Regulation of the Chairman of the National Land Agency No. 4 of the Year 1989 regarding the Form and Procedure for the Composing of Land Book and the Issuance of the Certificate of Right of Ownership over SRS ("HMSRS").

d. The formation of strata title resident association must comply with the provisions set out in the Decree of the State Minister of Public Housing as the Chairman of the National Agency for the Policy and Control of Housing and Settlement Construction No. 06/KPTS/BKP4N/1995 regarding the Guideline for the Drawing-up of the Deed of Establishment, Articles of Association and By-Laws of SRS Resident Association. 
State land (Hak Pakai/HP) or Right of Management (Hak Pengelolaan/HPL) in accordance with the prevailing statutory regulations. The organizing of construction, which builds Rumah Susun over a land possessed by HPL must settle the status of HGB over the HPL in accordance with the prevailing statutory regulations prior to selling the relevant SRS.

The development must separate HMSRS and common-parts in the form of drawings and description ratified by the authorized institution in accordance with the prevailing statutory regulations giving elucidation over:

a. boundaries of units which can be separately used for individual;

b. boundaries and description of common-parts and common-goods which become the entitlement of each SRS;

c. boundaries and description of common-land and the width of part which become the entitlement of each SRS.

\section{Occupancy and management of Rumah Susun.}

Residents in Rumah Susun neighborhoods, both residential and nonresidential, must form occupant associations to arrange and manage the communal right of the relevant party as its ownership, occupancy, and management.

An occupant association has the following functions:

a. foster the creation of healthy, orderly, and safe neighborhood;

b. arrange and foster the interest of the residents;

c. manage storey housing and its environs.

Occupant associations may represent the residents in performing legal action both before and outside the Court. The formation of resident association is conducted by drawing up a deed ratified by the Regent or Mayor of the Second Level Region, and, for the Special Region of the Capital City of Jakarta, by the Governor of the Region.

Members of occupant associations are subject of law, who own, use, rent, or lease, or utilize relevant storey housing unit in the capacity as a resident.

\section{Rumah Susun with lease system as an alternative (Rumah Susun Sewa or "Rusunawa").}

The Government, as one of the parties responsible for the arrangement of this slum settlement area has attempted various efforts to make their settlement environments worth occupying. One of the government programs is the construction of economical storey housing as an alternative to poor community occupying slum settlement as stipulated in Article 3 of the Presidential Instruction Number 5 of 1990 regarding Revitalization of Slum Settlement on State Land. ${ }^{12}$

The Provincial Government of the Special Region of the Capital City of Jakarta has made available budget worth Rp. 150 billion for the construction

\footnotetext{
${ }^{12}$ Article 3 of the Presidential Instruction number 5 of the year 1990 regarding Revitalization of Slum Settlement on State Land stipulates:

"Residents of the neighborhood being revitalized is re-allocated in Rumah Susun as the result of revitalization or other location nearby the location of revitalization, both by means of owning supported by Housing Ownership Credit facility and by leasing"
} 
14 blocks of Rusunawa. It is planned that the construction of Rusunawa will be developed in Marunda area and Kapuk Muara, North Jakarta. The construction of 14 twin-blocks of Rusunawa, according to the then Deputy Governor of the Province of the Special Region of the Capital City of Jakarta, Dr. Ing. H. Fauzi Bowo, was projected to be completed by the end of 2006. In addition, the construction of Rusunawa is considered as the most appropriate pattern to be developed in Jakarta.

In relation to the construction of Rusunawa consisting of 14 blocks, for the development of Marunda, the land owned by the Provincial Government of the Special Region of the Capital City of Jakarta is 40 hectares. In Marunda 9 blocks will be constructed; in Karet Tengsin, 2 blocks; and in Kapuk Muara, 3 blocks. Each block consists of 100 units of low-income SRS. Thus, it is projected that this construction of Rusunawa in the Special Region of the Capital City of Jakarta is totaling 2,040 units. Previously, the Governor of the Special Region, Sutiyoso, stated that the construction of Rusunawa has the objective of arranging the Capital City and simultaneously providing decent settlement for its residents. The plan for the construction of such storey housing is spread out in several locations:in Marunda area (1,500 units of six storied type 30 with land width of 227,514 m20, Karet Tengsin (292 units of 12 storied type 21), Pulo Jahe (48 units of 3 storied type 21), and Rawa Bebek (200 units of six storied type 36). ${ }^{13}$

However, in reality, people living in the Rumah Susun are in "financially capable" community group. It is not rare that the ownership of such SRS has been transferred to the second, third, and subsequent parties that are more financially capable. SRS, which was initially intended for low-income community has been sold, therefore, the target of Rumah Susun has not reached the target market.

In addition, in terms of maintenance aspects, most of the SRS are very minimum. Building colors have faded and building materials are no longer maintained. Non-maintenance of the building causes new dirtiness in the environment of the Rumah Susun dan SRS. Rumah Susun really stimulates efficiency in the use of land in a city as big as Jakarta, where land prices become higher, but the occupier or owner's ability to maintain his building is very far from expectation.

Several Rumah Susun are spread across Jakarta. In Central Jakarta, there are Petamburan Rumah Susun (600 units), Bendungan Hilir Rumah Susun (614 units), Karet Tengsin Rumah Susun (160 units), Tanah Tinggi Rumah Susun (428 units), and Jatibunder Rumah Susun (60 units). Even though the development of Rumah Susun is starting to intensely increase, there are only two developers in the form of government-owned companies (even though, actually, there has been regional government regulation which encourages private party to construct modest Rumah Susun) that massively develop modest Rumah Susun. Currently, Perumnas (the national housing government company) has managed approximately 8,000 units of modest Rumah Susun and PD (Regional government's Company) Sarana Jaya is managing not less than 3,000 units of modest Rumah Susun. ${ }^{14}$

${ }^{13}$ Processed from the source: http://www.indoproperty.com/forwarder.php3?link=artikel\&id_ news $=3284$, accessed on Wednesday, April 12, 2006

${ }^{14}$ Data is sourced from Kompas, March 26, 2002 
From the perspective of the occupier, the maintenance and operational cost of Rumah Susun is relatively becoming very expensive. The cost to purchase washing machine as solution to problems regarding hanging of laundry across the slums cannot be easily fulfilled. The cost for maintenance is very difficult since occupants' expenses are more prioritized for food and clothing. Since they are living together in one building, the maintenance of public space is sometimes overlooked. For example, with regard to the corridor and the painting of the outside part of the building, they shift the responsibility to one another.

In reality, Rumah Susun, which initially was constructed very orderly organized, has changed into a slum neighborhood. In several Rumah Susun can be seen the presence of puddle of water and scattered trash. Maintenance cost, which should be paid by the owner of the Rumah Susun (who mostly are middle-down community group), cannot be paid since the occupants must first consider their daily needs. Even in paying the rent, they sometimes settle in arrears. Aside from cost, adaption to Rumah Susun living is difficult since local dwellers often prefer parcels of land and occupy larger spaces for their families. Some people commented that living in a cramped area in Rumah Susun is causing them stress.

Alternatively, if indeed Rusunawa will be an alternative solution over housing issues for poor community groups, the government must resolve maintenance and other issues .

The government must provide financial support for maintenance. In comparison, in European countries, regional governments also have the obligation in the maintenance and supervision of buildings. There, change of color or repair of building façade is the responsibility of the regional government. However, regional governments in that region are subsidized by very high taxes.

\section{Role of local government in the development of Rumah Susun}

The government of the Regency/City, in the framework of performing its obligation in the sector of urban area and housing construction, has the tasks to: (1) direct and control the development of settlement in accordance with the city development and efficient service; (2) create cohesive social environment and prevent the occurrence of exclusivity; (3) provide basic infrastructure and facility service for settlement and urban area; and (4) ensure the organization of rights and security of its community in settlement affairs. ${ }^{15}$

The policy of the central government will finally be having more tendencies towards the efforts for the national stipulation, fostering, and facilitation in various programs that encourage settlement organization system and process in the regional level of regency and city. In addition, facility from the central government in the settlement sector is intended to encourage participation and active role of the community and the regional government in the formulation of plans and programs for the construction of their settlements. ${ }^{16}$

In the effort of regional autonomy organization related to the development of settlement, the following are recommended:

1. The regency/city government should be obliged to act as: (a) the Controller of

\footnotetext{
${ }^{15}$ As reflection of the provision of Article 199 in conjunction with Articles 13 and 14 of Law number 32 of the year 2004 regarding Regional Governance

${ }^{16}$ Article 199 paragraph (6) of Law number 32 of the year 2004 regarding Regional Governance
} 
Settlement Development; (b) the Organizer of Settlement Development; (c) the Supervisor of Improvement of Settlement Quality; (d) the Supervisor of Improvement of Integrity and Harmony of City. For such purposes, statutory regulations that are not yet inline with the spirit of Law, which puts forward the authority of autonomous region, needs to be immediately perfected and developed continuously.

2. It is necessary to immediately overcome the presence of impediments with regard to the limited capacity of the regional government as coordinator of development in its region, especially in organizing all settlement development potentials in the area. For such purpose, it is important to immediately conduct the improvement of regional capacity by means of national facilitation support from the central government to encourage the functioning of a settlement organizing system and process in the level of regency and city region.

3. Settlement development policy must be directed at the development of regional based settlement. Disorderliness will give negative impact to the existing surrounding environment.

4. In the framework of materializing the efficiency of such space and land, it is necessary to continuously improve implementation of spatial planning for transparent and participative settlement area.

\section{Impeding and supporting factors in the implementation and development of Rumah Susun in the urban area}

Slutti Lall (2003) who is a Professor of Society for Development Studies emphasizes the importance of legal aspect in the development of urban area, "The regulations had their original usage as tools of planned development. In the context of urban planning, regulations which are more appropriately termed as development standards, can be considered as the embodiment of the development plan it self as they are fundamental to any systemic attempt to achieve organized and planned development of the human settlement system." ${ }^{\prime 7}$

From the understanding focusing on the domain of legal science towards the prospect for the application of Rumah Susun development concept in the framework of settling population and slum area issue in urban area, the following briefly describe the impeding and supporting factors of such possibility.

\section{Impeding Factors}

\section{Incomplete subject matter of law}

In the framework of implementation of settlement over population issue in urban area with the development of Rumah Susun either being sold or leased (Rusunawa), sufficient ruling is required. This is to anticipate the occurrence of bias from the objectives of the construction of leased modest storey housing, which afterward becomes speculation practice and falls to the hand of the middle-economic class from the result of research and exposure in various mass media.

${ }^{17}$ Slutti Lall, "Settlement of the Poor and Guidelines for Urban Upgrading: Case Study of Alwar, A Secondary Town", paper at International Workshop on Integrated Urban Housing Development $17^{\text {th }}-18^{\text {th }}$ March 2003, held at the Schumacher Centre for Technology and Development Bourton Hall Burton-onDunsmore Rugby United Kingdom. 
In addition, in stipulating occupancy in Rusunawa, which already has technical guidelines issued by the Directorate General of Housing, the Ministry of Public Works should maintain the level of different occupancy at Rusunawa compared to Rumah Susun with SRS system. The practice in the Special Region of the Capital City of Jakarta, which has experienced in constructing and stipulating Rusunawa, should be improved by much better stipulation with a different understanding.

Another legal matter pertaining to Rumah Susun relates to the mechanism of stipulation over the procedure in the issuance of certificate of Right of Ownership over Storey Housing Unit (HMSRS). Law No. 16 of 1985 and Government Regulation No. 4 of 1988 provide direction for the stipulation by the respective regional government through Regional Government Regulation. The impediment is that not all of regional governments already have Regional Government Regulation, which enables the construction of storey housing together with its certification procedure. Moreover, in area surrounding Jakarta, such as Depok, SRS-system buildings have already emerged. However, Depok regional government has not enacted any government regulation that facilitates SRS system. As a solution, we [Q: who is "we"? The writer alone or a group of academics?] have presented a proposal to various parties (Regional Government, including the Special Region of the Capital City of Jakarta) regarding time and procedural impediments in issuing legal products in the form of Regional Government Regulation. It can replace the Decree of the Governor (outside of the Special Region of the Capital City of Jakarta by the Decree of the Regent/Mayor in the stipulation for the construction of Rumah Susun with SRS system).

Normative provisions regulating the sale and management of Rumah Susun and SRS should also be improved. Stipulations in Law Number 16 of 1985 and Government Regulation Number 4 of 1988 are not yet resolute and remain as causes of multi-interpretation (bias) in the subject of legal protection with regard to the sale and ownership of SRS as stipulated in the Decree of the State Minister of Public Housing No. 11/KPTS/1994 dated November 17, 1994, regarding Guideline for Sale and Purchase Binding of SRS. Our proposal is certainly a revision towards those two regulations (Law and Government Regulation), which is relevant in the framework of applying this concept with the expectation that multi-interpretation in the Decree of the State Minister of Public Housing will not be repeated and will have clear and adequate legal basis (including this crash-program).

\section{Cultural, social and urban area community factors}

Solution to population issues concerning low-income group of people who will occupy Rusunawa should be fostered socially and culturally. Living in Rumah Susun requires new and different understanding to the culture they previously practice, such as, improper disposal of garbage, disorganized house and environment arrangements in using emergency stairs, and utilization of yards. These usually compromise the aspects of comfortable, harmonious, and safety living in Rumah Susun.

Part of social condition is intergral to their economic capability. Their total income measured from Regional Minimum Wage eight hundred thousand rupiah per month is not enough to cover even maintenance of their houses. Moreover, 
during the present economic crisis, when prices of basic needs are very high, their priority is to fulfill their basic needs (food and clothing). For instance, if they spend one hundred and fifty thousand to three hundred thousand rupiah every month, what remains is not enough to cover their daily needs. Therefore, it is not surprising if target occupants of Rusunawa are modified - those who are financially more capable of paying the rent by means of speculation practice, which is not apart from direct and indirect involvement of regional government apparatus. $^{18}$

\section{Malfunctioning of inter-government agencies coordination and role of private sector}

From the legal aspects, weak coordination and regulation due to overlapping between vertical/central government agencies and the local government of the province (DKI Jakarta) and regencies/cities still emerge. In the scope of modest multi-storey rental housing regulation, not all regions have their own regulation or the existing regulation may be basically different from that of the Depkimpraswil.

In addition, there are related multi-sectors/multi-authorities in the function of the Ministry handling people's housing (the State Minister for People's Housing) with the Ministry of Public Works.

There are Housing Bureaus in regional, provincial, and regency/city levels. Those may have basic tasks and functions (tugas pokok, dan fungsi) that may overlap with other two ministries. Therefore, the multi-sectoral authorities related to the policy we propose here also require reformulation and revitalization of each agency having one scope and target, i.e. housing development (including Rumah Susun). It is expected to create synergy and optimal efficiency in the framework of applying modest Rumah Susun as well as Rusunawa development programs.

This will, of course, become constraints on urban area development system and demographical problems. The continuous phenomenon of urbanization in Jakarta as well as in Sumatra, West Java, Banten, Central Java, and East Java has overwhelmed the regional governments. Temporarily the megapolitan idea, as an umbrella concept to regulate Jakarta, Bogor, Puncak, Cianjur, Depok, and Tangerang as one region, is deemed to be a solution in terms of spatial plan. Of course, the implication of the spatial plan coordination model in such areas is expected to touch upon demographical aspects through the stipulation of appropriate development programs, including urban slum development.

On the private sector side, developers of Rumah Susun may be profitable because the land acquired is relatively smaller compared to that used in development of large-scale single housing. However, there is another constraint affecting the interests of the private sector. According to an expert, the price of each modest SRS can reach three to four times the price of very modest/ SRS. A study once made in DKI Jakarta in 2001-2002 on modest Rumah Susun development for industrial estate employees and transportation indicates that the regional government is still reluctant to facilitate development by allocating the regional government's asset lands.

\footnotetext{
${ }^{18}$ http://www.pu.go.id/bapekin/buletin\%20jurnal/buletin\%2011/buletin117.html
} 


\section{Supporting Factor}

\section{Population increase, urbanization, and economic sector improvement}

Efforts to control urbanization have been made many times. Among those are application of regulation on compulsory reporting to migrants to the local sub district office, the application of various requirements that must be met if wanting to be Jakarta inhabitants, and activities of Operasi Yustisi Kependudukan (OYK) that impose fines on migrants having no Jakarta identification card. However, these attempts have no significant impact on reducing migration flow to Jakarta, as proven by the increasing number of migrants ranging between 200-250 thousand per year during the period of 2002-2004 ${ }^{19}$. This statistics illustrate that the effort of controlling migration to the area of DKI Jakarta needs to be improved. In relation to this, information on the migration phenomena to DKI Jakarta (permanent and temporary) can be used as basic data in the effort of overcoming demographical problems as a result of migration.

Table 1: Population Development in DKI Jakarta and Botabek (1961 - 2000) [In million unit?]

\begin{tabular}{|l|r|r|r|r|r|}
\hline MUNICIPALITY & \multicolumn{1}{|c|}{ SP 1961} & \multicolumn{1}{|c|}{ SP 1971} & \multicolumn{1}{|c|}{ SP 1980} & \multicolumn{1}{c|}{ SP 1990} & \multicolumn{1}{c|}{ SP 2000 } \\
\hline Central Jakarta & $1,002.10$ & $1,260.30$ & $1,236.90$ & $1,074.80$ & 948.20 \\
\hline North Jakarta & 469.80 & 612.40 & 976.40 & $1,362.90$ & $1,697.00$ \\
\hline West Jakarta & 469.50 & 820.80 & $1,231.20$ & $1,815.30$ & $2,389.90$ \\
\hline South Jakarta & 466.40 & $1,050.90$ & $1,579.80$ & $1,905.00$ & $2,090.30$ \\
\hline East Jakarta & 498.70 & 802.10 & $1,456.70$ & $2,064.50$ & $2,595.00$ \\
\hline DKI Jakarta & $2,906.50$ & $4,546.50$ & $6,481.00$ & $8,222.50$ & $9,720.40$ \\
\hline REGENCY+MUNICIPALITY & & & & & \\
\hline Bogor & $1,257.80$ & $1,597.20$ & $2,493.90$ & $3,736.20$ & $5,423.30$ \\
\hline Tangerang & 817.20 & $1,025.70$ & $1,529.10$ & $2,765.00$ & $4,594.20$ \\
\hline Bekasi & 669.70 & 803.00 & $1,143.60$ & $2,104.40$ & $3,570.60$ \\
\hline BOTABEK & $2,744.70$ & $3,425.90$ & $5,166.60$ & $8,605.60$ & $13,588.10$ \\
\hline JABOTABEK & $5,651.20$ & $7,972.40$ & $11,647.60$ & $16,828.10$ & $23,308.50$ \\
\hline
\end{tabular}

Source: BPS DKI Jakarta

\section{Limited land in urban areas}

Other facts from data of land area in Jakarta in 2001 (minus Kepulauan Seribu) indicate trends towards increasing land use for office, warehouse, and housing and decreasing land in the form of park (open-space) and industry as seen in the table below.

\footnotetext{
${ }^{19}$ Data source based on results of Registration of Population of DKI Jakarta, 2004
} 


\section{TABLE 2}

LAND AREA AND ITS USAGE BY MUNICIPALITY DKI JAKARTA, 2001

(HECTARE)

\begin{tabular}{|c|c|c|c|c|c|c|}
\hline Municipality & Housing & Industry & $\begin{array}{c}\text { Office and } \\
\text { Warehouse }\end{array}$ & Park & Others & Area \\
\hline South Jakarta & $10,431.35$ & 236.08 & $1,568.05$ & 179.24 & $2,158.24$ & 14,573 \\
\hline East Jakarta & $13,445.22$ & $1,233.38$ & $1,473.68$ & 277.84 & $2,342.87$ & 18,773 \\
\hline Central Jakarta & $3,097.69$ & 54.13 & 971.41 & 138,91 & 527,85 & 4,790 \\
\hline West Jakarta & $8,559.27$ & 495.77 & $1,451.98$ & 127,41 & $1,980.55$ & 12,615 \\
\hline North Jakarta & $8,147.13$ & $1,714.13$ & $1,436.91$ & 463.57 & $3,639.25$ & 15,401 \\
\hline Total & $43,475.09$ & $3,228.21$ & $7,898.54$ & $1,270.11$ & $10,280.02$ & 66,152 \\
\hline 2000 & $41,331.32$ & $4,988.53$ & $6,812.75$ & $1,314.23$ & $11,705.17$ & $66,152.00$ \\
\hline 1999 & $43,230.00$ & $3,970.00$ & $6,955.00$ & $1,328.00$ & $10,669.00$ & $66,152.00$ \\
\hline 1998 & $43,488.71$ & $4,256.75$ & $6,898.30$ & $1,303.10$ & $10,205.14$ & $66,152.00$ \\
\hline 1997 & $44,454.14$ & $3,393.60$ & $7,455.33$ & $1,435.50$ & $9,413.43$ & $66,152.00$ \\
\hline 1996 & $44,566.60$ & $3,261.30$ & $7,124.57$ & $1,296.58$ & $9,902.95$ & $66,152.00$ \\
\hline
\end{tabular}

Source: BPS of DKI Jakarta Province

Limited land and continuous development/economic growth creates an imbalance. The need for land for important development purposes is usually not met.

\section{Aspirating legal matters}

It is very clear that aspirating legal matters---in relation to the application of development of Rumah Susun urban areas as an alternative to demographical problem solving, especially the effort of meeting the need for housing for lowincome and middle-income groups---are very aspirating and accommodative. This can be seen from Law Number 16 of 1985 and Government Regulation Number 4 of 1988.

The letter 'b' of the preamble of Law Number 16 of 1985 states that in the framework of increasing efficiency and effectiveness of land for housing development and of improving the environmental quality of settlements especially in areas where population is large and available land is limited, it is necessary to develop multi-storey housing system. It can be divided into parts and units that can be jointly owned and occupied considering social cultural factorsin society. Article 3 of Law Number 16 of 1985 also stipulates that the objectives of developing Rumah Susun are to meet the need for decent housing for the people guaranteeing legal certainty in its utilization; to improve efficiency and effectiveness of land in urban areas by considering the preservation of natural resources; and to create a complete, harmonious, and balanced settlement environment. 
According to Government Regulation Number 4 of 1988, the development of Rumah Susun with SRS system and regulation are directed to increase the effort of developing Rumah Susun and settlements that are functional for the benefit of the people. The Rumah Susun development and regulation are intended to support the spatial planning conception related to urban area development to the vertical direction and to rejuvenate refresh slums; increase the optimization of use of urban land resources; and encourage development of settlements with high population.

\section{Closing}

\section{Conclusion}

From the discussion about two issues related to demographical problemsolving in urban areas and Rumah Susun development above, it can be conclude that:

1. The possibility of implementing vertical housing (multi-storey housing) or the so-called Rumah Susun development in the framework of giving a solution to issues on demography and slums in urban areas may be the best alternative thereto for consideration:

a) normatively, there has been a legal base supporting this program especially in Law Number 16 of 1985;

b) factually, various data indicate that there is a trend towards the increasing population in urban areas requiring housing, and an issue on limited land for that purpose. To that end, the concept of Rumah Susun development in urban areas can be the best solution;

c) practically, there has been a development model like this especially in Jakarta (although it still requires more comprehensive regulation) and in other major cities in the world.

2. On the one hand, there are impeding factors in the form of legal subject matters that are not satisfactory or the implementation is not adequately coordinative in its nature or is not appropriate for the targeted population in slum area within the urban community in terms of social and cultural aspects and low economic capability. On the other hand, there are also supporting factors, such as facts related to the increase of urbanization and scarcity of land, which on the other hand also support starting and planning settlement programs for population issue and storey housing construction.

\section{Recommendations}

Based on the understanding of the open possibility of applying Rumah Susun development in the framework of demographical problem solving in urban areas, the following recommendations are given:

a). towards the impeding factors in the form of legal subject matters that are not satisfactory or the implementation is not adequately coordinative in its nature, there should be political will, transparency, and systematic restipulation; and 
b). towards supporting factors, they can be the initial assets to start and plan settlement programs for population issues and Rumah Susun development, accompanied by profound and comprehensive studies towards the supporting infrastructures (regulation and financing) and political supra-structures in regional autonomy era having immense potential to materialize this idea.

\section{Bibliography}

Lall, Slutti. "Settlement of the Poor and Guidelines for Urban Upgrading : Case Study of Alwar, A Secondary Town." International Workshop on Integrated Urban Housing Development. Dunsmore, 2003.

Soegijoko, Budhy Tjahjati S. "National Policy of Urban Area in entering into the Third Milennium." National Seminar on City Lay-Out Entering into the Third Millennium. 1999.

Stanley, Samuel R. "The Sprawling of America : In Defense of The Dynamic City." Brief Analysis of National Center for Analysis Policy no. 287, March 1999.

http://www.indoproperty.com/forwarder.php3link=artikel\&id_news=3284 (accessed April Wednesday, 2006).

http://kpu.go.id/dmdocuments/UU_32_2004_Pemerintahan Daerah.pdf (accessed April 2006).

http://www.menlh.go.id/serasi/serasi2.pdf (accessed April 2006).

http://prokum.esdm.go.id/uu/1999/uu-22-1999.pdf.

http://www/pu.go.id/bapekin/buletin jurnal/buletin 2011/buletin117.html. 